\title{
Cultural adaptation and reliability of the questionnaire of sex education in schools
}

\author{
Adaptação cultural e confiabilidade do questionário de educação \\ sexual em meio escolar
}

Anice de Campos Pássaro (https://orcid.org/0000-0001-9345-3284) ${ }^{1}$

Mariana Cristina Regra (https://orcid.org/0000-0003-4485-887X) ${ }^{1}$

Carla Serrão (https://orcid.org/0000-0001-6001-1164) ${ }^{2}$

Amélia Pasqual Marques (https://orcid.org/0000-0001-6705-7763) ${ }^{1}$

${ }^{1}$ Faculdade de Medicina, Universidade de São Paulo. anicepassaro@usp.br

${ }^{2}$ Escola Superior de

Educação, Instituto

Politécnico do Porto. Porto

Porto Portugal.

\begin{abstract}
Sexuality is embedded in a social and cultural origin and its approach must go beyond biological aspects. Questionnaire on Sex Education in Schools (QUSES) assesses the knowledge, comfort, motivation and involvement of teachers in relation to sex education. This article aims to culturally adapt and verify the reliability of QUSES. The Experts Committee realized the Cultural adaptation and content validation. The Cronbach's alpha and its stratification were tested for reliability. It was applied to 100 teachers with an average of 44.45 (9.62) years of age. Words and phrases were modified, maintaining the equivalences of the original version. Question of knowledge was the most modified due to regulatory differences between countries. Reliability data was similar to the original instruments and were considered good. The lowest values were $\alpha=$ 0.741 for subscale of efficacy of results, $\alpha=0.812$ and $\alpha=0.849$ for subscale of involvement (cognitive). QUSES was culturally adapted for Brazilian elementary schools teachers presenting good reliability. It is relevant, because it evaluates sex education fully and may support in implementation and monitoring public policies related to health promotion in schools.
\end{abstract}

Key words School health, Sexuality and psychosexual development
Resumo Sexualidade insere-se num cenário de controle social e cultural, portanto sua abordagem deve ir além dos aspectos biológicos. O Questionário de Educação Sexual em Meio Escolar (QUES$M E)$ avalia o conhecimento, o conforto, a motivação e o envolvimento dos/as professores/as em relação à educação sexual. O objetivo deste artigo é adaptar culturalmente e verificar a confiabilidade do QUESME. Foi realizada adaptação cultural e validação de conteúdo pelo comitê de especialistas. Para a confiabilidade utilizou-se o alpha de Cronbach e sua estratificação. Foi aplicado a 100 professores/as com idade média de 44,45 $(9,62)$ anos. Expressões foram modificadas mantendo-se o conteúdo da versão original. A questão sobre conhecimento foi a mais modificada devido às diferenças normativas dos países. A confiabilidade foi semelhante ao instrumento original: os menores valores encontrados foram $\alpha=0,741$ para eficácia de resultado, $\alpha=0,812$ e $\alpha=0,849$ para envolvimento cognitivo. Conclusão: O QUESME foi adaptado culturalmente para o Brasil apresentando boa confiabilidade. É relevante, pois avalia as ações de educação sexual amplamente, podendo auxiliar na implementação e acompanhamento de políticas públicas relacionadas à promoção de saúde nas escolas.

Palavras-chave Saúde escolar, Sexualidade e desenvolvimento psicossexual 


\section{Introduction}

Sexuality is an important component of personality and cannot be disconnected from other aspects of life. The term "sexuality" arose in the nineteenth century, related to biological and social behaviors, but require being understood as social evolution linked to historical, political, economic and social contexts ${ }^{1}$. This is redefined in 2002, according to the World Health Organization: "As a central aspect of human being that accompanies all life and which involves sex, identity, gender roles, sexual orientation, eroticism, pleasure, intimacy and reproduction (...). Sexuality is influenced by interaction of biological, psychological, social, economic, political, cultural, ethical, legal, historical, religious, and spiritual factors"2.

Sexuality is included in a social and cultural control context, so understanding needs to go beyond biological aspects such as contraceptive methods and sexually transmitted infections. That is, sexual education should allow each person to assimilate ethical, attitudinal and behavioral references. However, in undergraduate degree of physiotherapy and other health professionals, the sexuality is not being taught in full context.

In Brazil, the Health at School Program ${ }^{3}$ (Ordinance no. 3.682, 25 November 2010) offers a biological and informative vision of sexuality. Moreover, it is common in a school environment that only teachers of scientific discipline discuss sex education ${ }^{4}$. For other teachers, talking about sexuality can be difficult because they do not receive a sufficient orientation ${ }^{4}$. In this way, promoting workshops in health services and schools can contribute effectively to solving social and sexual issues ${ }^{5-7}$.

In Portugal, legal provisions relating to the promotion of health and sex education in school appeared at end of last century (Law no. 120/1999 of August $11^{\text {th }}$, Decree-Law no. 259/2000 of October $17^{\text {th}}$; Dispatch no. 25995/2005 of December $16^{\text {th }}$, Law no. 60/2009 of August $6^{\text {th }}$ e Ordinance no.196 A/2010 of April $9^{\text {th }}$ and others). These provisions established a school's compromise to develop health promotion programs, particularly by developing actions to promote sex education ${ }^{8}$.

Given these normative and legal frameworks, the Questionnaire on Sex Education in Schools (QUSES) ${ }^{9}$ was developed to analyze socio-cognitive variables that allow understanding the teach- er involvement predictors in promotion of sexual health. Although it has 27 questions, application time is only 30 minutes. The questions are clear, easy to understand and answered on a Likert scale of 0 to 6 .

QUSES is an interesting sex education instrument, which evaluates knowledge in relation to current legislation and some socio-cognitive variables, such as: (i) the comfort felt by teachers in relation sexuality issues; (ii) the motivation, analyzed by importance degree related by participants referring of sex education promotion, by self-efficacy degree felt by teacher in performing actions in sex education and by effectiveness of result, which refers to teacher's expectations about consequences (positive, negative, neutral) of sex education; (iii) the behavioral and cognitive involvement of participants in specific actions of sex education?.

Although studies in sex education are increasing in Brazil, these are still scarce and qualitati$\mathrm{ve}^{4,10-14}$. In this way, QUSES can bring an important aid to Brazilian education through analysis of socio-cognitive variables that could facilitate teacher's involvement in sex education programs. Furthermore, it can contribute to implementation and monitoring of public policies related to a school's health promotion. With QUSES instrument the physiotherapist will can to participate in development, application, and evaluation of public policies, applying the sexuality concept beyond body and dysfunctions.

The aim of this study is to culturally adapt and verify the reliability of Questionnaire on Sex Education in Schools (QUSES) for Brazilian elementary school teachers.

\section{Method}

The choice of QUSES instrument was defined after the databases literature review: Biblioteca Virtual em Saúde, PubMed, SciELO e Web of Science. Due to difficulty in locating sex education instruments with primary school educators (children), we resorted to the Google Scholar search tool, where we could locate QUSES.

This is a methodological study of cultural adaptation, validation of content and reliability of a self-responder questionnaire that evaluates four dimensions: knowledge, comfort, motivation and involvement of teachers in relation to sex education. 


\section{QUSES Instrument}

The QUSES presents an initial part of sociodemographic characterization and consists of four scales: scale of knowledge regarding legislation and ministerial guidelines on sex education; scale of comfort in relation to themes of sexuality; scale of motivation (consisting of three subscales: importance, self-efficacy and result efficacy) and scale of involvement (consisting of two subscales: cognitive involvement and behavioral involvement).

The scale of knowledge related to legislation includes 15 items, and the options are: true, false or do not know. The final result ranges from 0 to 15 by the sum of correct answers.

The comfort scale analyzes comfort felt by teachers in approaching themes related to sexuality. It consists of 30 items with options on a Likert scale, ranging from 1, very uncomfortable to 6 , very comfortable. The average score out of 30 items constitutes the overall comfort rating.

The motivation scale integrates 3 subscales (i) importance (19 items); (ii) self-efficacy (19 items) and (iii) result efficacy (8 items). Responses are given on a Likert scale with six points.

Finally, the scale of involvement includes 29 items: i) behavioral involvement (15 items): promote sex education actions in teacher's task; ii) cognitive involvement (14 items): opinions and beliefs of participants regarding teacher and school's role in sex education. All answers are given on a Likert scale with six answers types. The final results are items' mean corresponding to each scale (Table 1).

The exploratory factorial analysis was used at the original instrument and was indicated two constructs for the scale of result's efficacy: $1^{\text {st }}$ Factor (5 items-5, 1, 2, 3, 7) refer to positive beliefs, as the sex education promotion may arouse personal and social skills, and the $2^{\text {nd }}$ Factor ( 3 items $-6,4,8$ ) have negative / neutral beliefs, as the sex education promotion may induce sexual behaviors.
For scale of involvement were indicated three factors. The $1^{\text {st }}$ Factor (15 items - 13,6,7,2,1,10,1 $1,3,12,5,8,4,14,9,15)$ means involvement in practice teachers by proactive actions. The $2^{\text {nd }}$ Factor (6 items - 26,25,28,24,27,22) means involvement in educational relationship by teacher's perception, student needs and interests. The $3^{\text {rd }}$ Factor (6 items-18, 17, 16, 23, 20,19) means involvement in post, through individual judgment in relation to teachers and schools functions. The items 21 and 29 were excluded by Kaiser rule (not reached saturation load defined $\geq 0,40)$. The other scales were unidimensional.

Considering the factorial analysis of the original instrument, our study consisted of two steps. The first step focused on cultural adaptation and content validation. The second step tested the reliability of items in the questionnaire.

\section{Phase 1 - cultural adaptation and content validation}

Firstly, QUSES authors authorized the process Cultural adaptation and validation. Than we followed literature recommendation steps for required cultural adaptation: translation, synthesis of translation, back-translation, expert committee and pre-test of pre-final version ${ }^{15-17}$.

How the original questionnaire is in Portuguese language then is possible execute only steps four and five of guidelines ${ }^{15,16}$. However, are few studies that not do these first three steps, so we resolve to maintain all steps recommended. We only changed the $3^{\text {rd }}$ step with one and not two native translator from Portugal ${ }^{16,18}$.

1. Translation: Two independent translators translated the QUSES from Portugal-Portuguese to Brazilian-Portuguese: a retired teacher aware the theme of the questionnaire, and another translator, a public administrator who was unaware of the theme of questionnaire. Both received the original printed questionnaire and they highlighted the words to be altered or adapted to the current

Table 1. Scales that make up the QUESME, with a total number of items, minimum and maximum of the scales.

\begin{tabular}{llcl}
\hline \multicolumn{1}{c}{ Scales } & Items & \multicolumn{1}{c}{ Minimum/ maximum } \\
\hline Knowledge & & 15 & True / False / Do not know \\
Comfort & & 30 & 1-very uncomfortable / 6-very comfortable \\
Motivation & Importance & 19 & 1-no importance / 6-much importance \\
& Self-efficacy & 19 & 1-nothing capable / 6-very capable \\
& Result Efficacy & 08 & 1-does not believe / 6-believe too much \\
Involvement & Behavioral & 15 & 1-never / 6-always \\
& Cognitive & 14 & 1-strongly agree / 6- strongly disagree \\
\hline
\end{tabular}


use in Brazil. These words were transcribed in a report prepared by the translators.

2. Synthesis of Translation: The translators assessed the discrepancies and consolidated the Brazilian-Portuguese version;

3. Back translation: One native Portuguese-speaking translator (Portugal) back-translated the consolidated Brazilian-Portuguese version into Portuguese (Portugal). She did not have access to the original version of the QUSES. At this stage, a report was prepared justifying the suggested changes, ensuring the similarity of both questionnaires.

4. Expert committee: A steering committee consisting of retired teacher (translator of step 1), two elementary school teachers, one linked to sex education projects and other graduated in Languages, a university professor with experience in adaptation and validation of questionnaires, and a physiotherapist of women's health. The committee of experts had access to the following materials: the original instrument, the consensus version, and respective reports (steps 1-3) ) $^{15,16}$.

At the beginning of the process to content validity, the printed and digital material was delivery to all members ${ }^{15,16}$. The translators and experts' committee were requested to estimate the meaning equivalence for translated items, both for specific words and for sentences, and account them to four specific features: i) the semantic equivalence; ii) the idiomatic equivalence, iii) the item equivalence and iv) the concept equivalence. In addition, the meeting was recorded with the consent of the participants. During the meeting, all items were read by a physiotherapist researcher to recover the previous content delivered. The translators' suggestions were read separately after the consensus these. If there was not agreement among experts, the proposals were verified and headed to voting. In addition the audio recording of the session, annotations done by researchers served as support for this measurement validation step.

5. Pre-test of pre-final version: after the steering committee reached a consensus, the Brazilian-Portuguese version of QUSES was applied to 43 voluntary teachers to identify mistakes and divergences in translation. The expression "I do not understand" was added to the options; questions receiving more than $15 \%$ "I do not understand" answers would be analyzed and replaced with other items of the same concept ${ }^{17}$. Moreover, in a specific area left at the end of the questionnaire, the teachers could describe reasons for not understanding items they'd marked with "I do not understand".
As only 12 items presented the answers "I do not understand", with percentage less than 15\%, there were no changes in the questionnaire after this step $^{17}$.

The inclusion criteria were: (1) be an elementary teacher; (2) be in a traditional and/or constructivist school. The exclusion criteria was: (1) be in a Montessori and Waldorf school.

\section{Phase 2 - Reliability: statistical estimation}

The final version was applied to 100 teachers, selected for convenience for assessment of internal consistency. The inclusion criteria were: (1) be an elementary teacher; (2) be in a traditional and/or constructivist schools. The exclusion criteria was: (1) be in a Montessori and Waldorf schools. All participants signed approved informed consent forms for this step.

\section{Data analysis}

To measure validity, the content validation was performed, verifying the relevance of each item/domain in the studied construct ${ }^{5}$. This validation ensued after the consensus meeting.

According to Maroco e Garcia-Marques ${ }^{21}$, 2006 the alpha index contributes to estimate uniformity of items, in unweighted sum of instrument (scale of 0 to 1 ). In practice, Cronbach's alpha $^{19-21}$ is a lower-bound estimate of reliability, so its use is controversial in literature ${ }^{22-24}$. Therefore our decision was to apply both tests: Cronbach's alpha and stratified Cronbach's alpha reducing limitations described in literature ${ }^{21,25}$.

Nunally e Bernstein ${ }^{26}$ consider acceptable for the initial phases of investigation the Cronbach's alpha value equal to $0.70 / 0.80$, but in important decisions should be considered the minimum value of 0.90 .

\section{Ethics committee approval}

The present study followed the ethical precepts of research in humans regulated by Resolution $n^{\circ} 196 / 96$ of National Council of Health/ Ministry of Health and the Code of Ethics for the Physical Therapist COFFITO 424/2013 (Federal Council of Physiotherapy and Occupational Therapy). All participants were informed about the research procedures in questionnaire instructions, keeping the prerogative to take away any time their consent to participate.

The study was approved by the Ethics Committee of the Faculty of Medicine, University of São Paulo, Brazil. 
All participants signed approved informed consent forms for this step of the study.

\section{Results}

\section{Characterization of Participants}

A hundred teachers were included in this study and displayed the following characteristics: $76 \%$ female and age $44,45(9,62)$ years. Regarding sexual orientation: $89 \%$ heterosexual, $48 \%$ married, $25 \%$ singles, $16 \%$ stable union, $10 \%$ divorced, and $1 \%$ widow/er. In relation to schooling, $52 \%$ complete higher education, $28 \%$ post-graduate Latu Sensu, 13\% incomplete master, 2\% incomplete doctorate and $1 \%$ complete master. In relation to time of activity in current school: $25 \%$ were working between 16 and 20 years, $21 \%$ between 21 and 25 years; $18 \%$ more than 26 years; $17 \%$ between 11 and 15 years, $12 \%$ between 6 and 10 years, finally $7 \%$ between 1 and 5 year. Table 2 reveals other characteristics from the sample.

\section{Cultural adaptation}

There was an equivalence adaptation: i) in the initial part (instruction) of the questionnaire explaining the study and how it should be responded to, and ii) in 21 of 27 questions that made up the original questionnaire. Table 3 exemplifies the modifications.

The item 20, querying knowledge regarding ministerial legislation and regulations underwent major changes due to differences between two countries. The institutional instances and the school years were modified.

\section{Reliability: statistical estimation}

The consistency estimate of data by Cronbach's alpha evidenced high reliability for all scales, as verified in Table 4. To subscale efficacy of result, the items that compose the $2^{\text {nd }}$ factor presented less reliability $(\alpha=0,741)$ as well as the $2^{\text {nd }}$ and $3^{\text {rd }}$ factors of subscale of cognitive involvement, with $\alpha=0.849$ and $\alpha=0.812$, respectively. Considering the multidimensional scales, we also calculated stratified Cronbach's alpha $\left(\alpha^{\prime}\right)$.

\section{Discussion}

The aim of this study was to culturally adapt and verify reliability of the Questionnaire on Sexual
Table 2. Characteristics of the sample in relation to the type of school, area of activity, time in the profession and religious belief.

\begin{tabular}{llr}
\hline \multicolumn{2}{c}{ Characteristics of the participants } & $\%$ \\
\hline School & Public school & 84 \\
that & Municipal and state school & 6 \\
teaches & Private school & 5 \\
& State and private school & 3 \\
& Municipal School & 1 \\
& Municipal and private school & 1 \\
Area & Humanities (arts, music, & 51 \\
acting in & history, geography, letters and & \\
the school & pedagogy) & \\
& Biological (physical education & 19 \\
& and science) & \\
& Mathematics & 21 \\
Time & Other (polyvalent) & 25 \\
in the & Between 16 and 20 years & 21 \\
profession & Metween 21 and 25 years 26 & 18 \\
& Between 11 and 15 years & 17 \\
& Between 6 and 10 years & 12 \\
& Between 1 and 5 years & 7 \\
Religious & Catholics & 58 \\
Belief & Spirits & 14 \\
& Without religion & 12 \\
& Protestants & 8 \\
& Others & 8 \\
\hline
\end{tabular}

Education in School (QUSES) for Brazilian elementary school teachers. The QUSES was culturally adapted for Brazilian elementary school teachers with good reliability.

Words and expressions with different meanings had been modified in the translated version, keeping contents of the original version, to validate the instrument properly. For example: "marital status" was replaced by "civil status"; "action had" replaced by "activity developed"; "academic qualifications" replaced by "academic education" and "AIDS" replaced the term "SIDA", because abbreviations and Anglo-American ter$\mathrm{ms}$ are incorporate into our culture.

In the Brazilian version, question 21, the technical terminology was added and the original term was identified in parentheses, so "wet dreams" was replaced by "nocturnal emission (wet dreams)" and "morning after pill" replaced by "emergency contraception (morning after pill)".

Question 25 was changed in descriptive content in agreement with the committee of experts. The scale of 1 to 6 , in the original version, was 


\begin{tabular}{|c|c|c|c|}
\hline 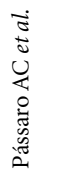 & Table 3. Origi & al items and the modifications made to & ural adaptation of QUSES. \\
\hline & Questions & Original Items & Modified Items \\
\hline & 1 & Marital status / De facto union & Civil Status / Stable Union \\
\hline & 6 & Academic qualifications & Academic education \\
\hline & 14 & Action had / Session & Activity developed / Training \\
\hline & 17 & Overall positive & Fully satisfactory \\
\hline & 19 & Active & Direct \\
\hline & 20 & Cross country & For the Ministry of Education \\
\hline & & Executive Councils & School management \\
\hline & & A protocol & A joint policy \\
\hline & & Pre-school education & Early Childhood Education \\
\hline & & $1^{\text {st }}$ cycle & $1^{\text {st }}$ year of elementary school I \\
\hline & & $2^{\text {st }}$ cycle & $6^{\text {st }}$ year of elementary school I \\
\hline & & $3^{\text {st }}$ cycle & $7^{\text {st }}$ year of elementary school I \\
\hline & & In secondary education & High school \\
\hline & 21 & SIDA & AIDS \\
\hline & & Wet dreams & Nocturnal emission (Wet Dreams) \\
\hline & & Morning after pill & Emergency contraception (morning after pill) \\
\hline & & Consultations for young people & Clarifications of doubts \\
\hline & 22 & Executive Council & School management \\
\hline & & In charge of education & Responsible for the student \\
\hline & 23 & I intend to develop & I plan to develop \\
\hline & 24 & To do & From tackling issues \\
\hline & & To do & From guiding on \\
\hline & 25 & I hardly believe & I doubt it a little \\
\hline & & Do not believe more than I believe & I Doubt \\
\hline & & I believe more than I do not believe & I believe a little \\
\hline & 26 & I do sex education & I approach to Sex Education \\
\hline & 27 & I feel that I am collaborating & I feel I collaborate \\
\hline
\end{tabular}

Table 4. Variables that compose the QUSES, dimensionality of measured constructs (factors) and reliability ( $\alpha$ Cronbach's alpha and $\alpha^{\prime}$ - stratified Cronbach's alpha).

\begin{tabular}{|c|c|c|c|c|c|}
\hline \multirow{2}{*}{ Scales } & & \multirow{2}{*}{ Factor } & \multicolumn{3}{|c|}{ QUSES } \\
\hline & & & \multicolumn{2}{|c|}{ Brazil } & Portugal \\
\hline Comfort & & 1 & $\alpha=0.984$ & $\alpha^{\prime}=0.985$ & 0.98 \\
\hline \multirow[t]{4}{*}{ Motivation } & Importance & 1 & $\alpha=0.978$ & $\alpha^{\prime}=0.979$ & 0.97 \\
\hline & Self-efficacy & 1 & $\alpha=0.984$ & $\alpha^{\prime}=0.985$ & 0.97 \\
\hline & Result Efficacy & 1 & $\alpha=0.945$ & $\alpha^{\prime}=0.945$ & 0.92 \\
\hline & & 2 & $\alpha=0.741$ & $\alpha^{\prime}=0.740$ & 0.69 \\
\hline \multirow[t]{3}{*}{ Involvement } & Behavioral & 1 & $\alpha=0.960$ & $\alpha^{\prime}=0.960$ & 0.94 \\
\hline & Cognitive & 2 & $\alpha=0.849$ & $\alpha^{\prime}=0.858$ & 0.81 \\
\hline & & 3 & $\alpha=0.812$ & $\alpha^{\prime}=0.813$ & 0.73 \\
\hline
\end{tabular}

considered extremely complex because there was incoherence between the minimum, ("I do not believe") and maximum ("I believe very much"), mainly for level 2 ("I hardly believe"), 3 ("Do not believe more than I believe") and 4 ("I believe more than I do not believe"). In this way level 2 was replaced to "I doubt it a little", 3 to "I doubt" and 4 to "I believe a little".
The question of knowledge about the law and ministerial orientation was the most altered due to regulatory differences of countries. The term "country" had been replaced by "Ministry of Education", because the function of this ministry in Brazil is to elaborate a national education policy. It was understood that other terms in Portugal, like "executive board," referred to "school 
management" and "protocol" to "joint policy" in Brazil.

Another important modification was in relation to preschool and regular grade school, due to differences in the educational systems between countries. The term "pre-school education" was replaced with "early childhood education".

In Portugal, there are 2 levels for scholarly education: basic and secondary. The basic education is divided into 3 cycles: i) $1^{\text {st }}$ cycle: firsts 4 years $(6$ to 9 years); ii) $2^{\text {nd }}$ cycle: more 2 years ( 10 and 11 years) and iii) $3^{\text {rd }}$ cycle: last 3 years $(12,13$ and 14 years). Considering this, the committee decided to replace " $1^{\text {st }}$ cycle" to " $1{ }^{\text {st }}$ year of elementary school I"; " $2^{\text {nd }}$ cycle" to " $6^{\text {th }}$ year of elementary school II"; " $3^{\text {rd }}$ cycle" to " $7^{\text {th }}$ year of elementary school II" and "secondary education" to "high school". The decision to replace " 2 nd $c y c l e$ " to " 6 th $y e a r$ of elementary school II" and not $5^{\text {th }}$ year was based on an understanding by the committee, that in the Brazilian educational system, this would be the mark of passage from elementary school I to II.

Although the Brazilian educational system has it's own two stages (I and II), to exclude the $3^{\text {rd }}$ cycle of Portugal was unacceptable. The members considered important to query about sex education from $7^{\text {th }}$ year, because there is a great difference of maturity and content between these years.

The scale of knowledge not gone through reliability test due to its content ${ }^{9}$. In the other scales, values found in present studies are in agreement with the original instrument, with the exception being the scale of efficacy of results ( $2^{\text {nd }}$ Factor). We observed value of alpha (0.741) higher than on original instrument (0.69). Just like this, the scale of involvement (cognitive) showed values of alpha below to 0.90 for $2^{\text {nd }}$ and $3^{\text {rd }}$ factors ( $\alpha$ $=0.849$ e $\alpha=0.812$, respectively), but still within acceptable range ${ }^{26}$.

The Cronbach's alpha underestimates true reliability in multidimensional scales, since it is affected by items quantity. In these cases, the stratified alpha can be considered a better estimate, although results may differ by only $1 \%{ }^{21}$. After achieving this homogeneity of items by stratification, the results were very close without considering the stratification, confirming the adequate statistical estimation of measurement consistency of QUSES. Still that, the values found for alpha were acceptable to study phase $\mathrm{e}^{21,26}$.

The absence of construct validation through confirmatory factor analysis may be considered a limitation for this phase of the study. However, in practice, any instrument will have its validation consecrated through its use in different popula- tions and contexts. Thus, the time the instrument is used will be the best method to assure its reliability and reproducibility ${ }^{21}$.

The reproducibility by test-retest was not used because the QUSES is used to measure psychological characteristics, so the first contact with the instrument may provoke thoughts that will change the individual's responses in a second assess with the instrument ${ }^{21}$.

Currently, the sexual health is considered as part of health promotion. So studies in Brazil that helps in data collection systematization to analyze how teachers, students, parents and health professionals comprehend sex education will aid to achieve sexual health.

In recent studies, Pinto et al. ${ }^{27}$ developed and validated an instrument for evaluation of health promotion in school. In the study, although sexuality appeared as an important factorial load for pedagogical dimension, the theme had to be excluded from the structural dimension of the instrument due to the existence of informational materials on gender and sexuality in the common areas of the school, this thematic couldn't be analyzed by instrument in 52 of the 53 schools visited, and had to excluded ${ }^{27}$.

Therefore, QUSES can aid to evaluate the Brazilian teachers of elementary education in relation to sex education. Its use may support in implementation and monitoring of public policies related to health promotion in schools.

\section{Conclusions}

The QUSES was culturally adapted for Brazilian elementary school teachers presenting good reliability. It is relevant, because evaluates to sex education fully and may support in implementation and monitoring of public policies related to health promotion in schools.

\section{Collaborations}

AC Pássaro worked on the conception, design, analysis, interpretation of data and drafting critically the article; MC Regra worked on the conception, design and approval of the version to be published; C Serrão worked on the critical review and approval of the version to be published and AP Marques worked on the conception, design, interpretation of results, critical review and approval of the version to be published. 


\section{Acknowledgments}

We sincerely thank Cláudia Viegas Saraiva, Guilherme Cyrino Carvalho, José Carlos Carreiro, Marisa Branco and Mónica Rua dos Santos. This project would not be completed without the effort from this committee.

\section{References}

1. Foucault M. História da Sexualidade: o uso dos prazeres. São Paulo: Paz e Terra; 2014.

2. World Health Organization (WHO). Defining Sexual Health: Report of technical consultation on sexual health 28-31 January 2002, Geneva. Sex Heal Doc Res 2006; (January):0-30.

3. Brasil. Ministério da Saúde (MS). Cadernos de Atenção Básica: Saúde na Escola. Brasília: MS; 2009.

4. Moizés JS, Bueno SMV. Compreensão sobre sexualidade e sexo nas escolas segundo professores do ensino fundamental. Rev da Esc Enferm 2010; 44(1):205-12.

5. Ressel LB, Gualda DM. A sexualidade como uma construção cultural: reflexões sobre preconceitos e mitos inerentes a um grupo de mulheres rurais. Rev Esc Enferm USP 2003; 37(3):82-87.

6. Beiras A, Tagliamento G, Toneli MJF. Crenças, valores e visões: trabalhando as dificuldades relacionadas a sexualidade e gênero no contexto escolar. Aletheia 2005;(21):69-78.

7. Cruz LMB, Loureiro RP. A comunicação na abordagem preventiva do câncer do colo do útero: Importância das influências histórico-culturais e da sexualidade feminina na adesão às campanhas. Saúde Soc 2008; 17(2):120-131.

8. Machado B, Noites V, Silva V. Projecto P.E.S. Promoção e Educação para a Saúde. Lisboa: DGS; 2011.

9. Serrão CSLS. Práticas de educação sexual em contexto escolar. Porto: Universidade do Porto; 2009.

10. Silveira GF, Wittkopf PG, Sperandio FF, Pivetta HMF. Produção científica da área da saúde sobre a sexualidade humana. Saúde Soc 2014; 23(1):302-312.

11. Jaques AE. Significado da sexualidade e assuntos correlatos no contexto escolar por professores do ensino fundamental na educação sexual: experiência de uma pesquisa-ação. São Paulo: Universidade de São Paulo; 2012.

12. Quirino GS, Rocha JBT. Sexualidade e educação sexual na percepção docente. Educ em Rev 2012; 43(jan/ mar):205-24.

13. Martin SAF. Educação sexual na escola: concepções $e$ práticas de professores. São Paulo: Universidade Estadual Paulista; 2010.

14. Belo MSP. Educação Sexual em meio escolar: perspectivas dos professores. Lisboa: Universidade de Lisboa; 2009.

15. Guillemin F, Bombardier C, Beaton D. Cross-cultural adaptation of health-related quality of life measures: Literature review and proposed guidelines. J Clin Epidemiol 1993; 46(12):1417-1432.
16. Beaton DE, Bombardier C, Guillemin F, Ferraz MB. Guidelines for the process of cross-cultural adaptation of self-report measures. Spine 2000; 25(24):31863191.

17. Marques AP, Mendes YC, Taddei U, Pereira CAB, Assumpção A. Brazilian-Portuguese translation and cross cultural adaptation of the activities-specific balance confidence (ABC) scale. Brazilian J Phys Ther 2013; 17(2):170-177.

18. Paz EPA, Parreira PMS, Serra AJ, Palasson LRR, Farias SNP. Adaptação transcultural do questionário de satisfação com os cuidados primários de saúde. Acta Paul Enferm 2014; 27(5):419-426.

19. Pilatti LA, Pedroso B, Gutierrez GL. Propriedades Psicométricas de Instrumentos de Avaliação : Um debate necessário. RBECT 2010; 3(1):81-91.

20. Cronbach LJ. Coefficient alpha and the internal structure of tests. Psychometrika 1951; 16(3):297-334.

21. Maroco J, Garcia-Marques T. Qual a fiabilidade do alfa de Cronbach? Questões antigas e soluções modernas. Laboratório Psicol 2006; 4(1):65-90.

22. Sijtsma K. On the Use, the Misuse, and the Very Limited Usefulness of Cronbach. Psychometrika 2009; 74(1):107-120.

23. Puhan MA, Bryant D, Guyatt GH, Heels-Ansdell D, Schünemann HJ. Internal consistency reliability is a poor predictor of responsiveness. Health Qual Life Outcomes 2005; 3:33.

24. Bentler PM. Alpha, Dimension-Free, and Model-Based Internal Consistency Reliability. Psychometrika. 2009; 74(1):137-143.

25. Heo M, Kim N, Faith MS. Statistical power as a function of Cronbach alpha of instrument questionnaire items. BMC Med Res Methodol 2015; 15(1):86.

26. Nunnally JC, Bernstein IJ. Teoria psicométrica. $3^{\mathrm{a}} \mathrm{ed}$. México: McGraw Hill/Interamericana de México; 1995.

27. Pinto RO, Pattussi MP, Fontoura LP, Poletto S, Grapiglia VL, Balbinot AD, Teixeira VA, Horta RL. Validation of an instrument to evaluate health promotion at schools. Rev Saude Publica 2016; 50:2.

Artigo apresentado em 26/06/2017

Aprovado em 19/09/2017

Versão final apresentada em 21/09/2017 